\title{
Transition from Millennium Development Goals (MDGs) to Sustainable Development Goals (SDGs): Blueprint of Bangladesh for Implementing the Sustainable Development Goals (SDGs) 2030
}

\author{
Musfiqa Ashraf ${ }^{* 1}$, Lokiat Ullah ${ }^{2}$, Muqsuda Ashraf Shuvro ${ }^{3}$, Umme Salma ${ }^{4}$
}

\begin{abstract}
Introduction: The Sustainable Development Goals 2030, titled "Transforming Our World: The 2030 Agenda for Sustainable Development" with 17 goals and 169 targets (including 43 means of implementation) were adopted at the United Nations in September 2015. The Seventh Five Year Plan of Bangladesh (SFYP), "Accelerating Growth, Empowering Every Citizen" for the years 2016-2020, produced by General Economics Division, Planning Commission, can be regarded as the blue print for the early critical phase of Sustainable Development Goals (SDG) implementation. Materials \& Methods: This Review Article was prepared based on updated International Newsletter, Journal and Data from Bangladesh Government Planning Commission. Discussion: Challenges of Sustainable Development Goals (SDGs) and 7th Plan include resource mobilization, tapping population momentum, managing unplanned urbanization, natural disasters and climate change, utilization of resources, skill development and quality education, improving competitiveness, governance, taming inequality and regional disparity. Bangladesh prepared its own post-2015 Development Agenda and contributed to the international discourse through UN. Conclusion: The General Economics Division (GED) of the Planning Commission, based on a consultative process initiated in 2013, goals and targets were developed in the context of Bangladesh. Through this process, 11 goals along with 58 targets with corresponding 241 measurable indicators were proposed. Civil society in Bangladesh also produced what is described as "a people-centred, equitable, inclusive, and sustainable Post-2015 Development Agenda." It came up with 13 Goals, 50 Targets and 199 Indicators.
\end{abstract}

Keywords: MDGs, SDGs, Sustainable Development Goals for 2030, 7th Five Year Plan of Bangladesh, Civil society SDG Agenda, Sustainable Development Goals and targets.

Number of Tables: 05; Number of References: 25; Number of Correspondences: 04

*1. Corresponding Author: Musfiqa Ashraf

Assistant Professor

School of Social Science

Humanities \& Languages

Bangladesh Open University, Gazipur- 1217.

Email: musfiqa3110@yahoo.com

2. Dr. Lokiat Ullah

Executive Director

Biopharma Ltd.

3. Dr. Muqsuda Ashraf Shuvro

MBBS, DMUD, FCPS (Gynae \& Obs)

Trained in infertility

Consultant

Hope Infertility Centre, Dhaka.

4. Dr. Umme Salma

Assistant Surgeon

OSD DG Health., DMU, M D

Department of Nuclear Medicine, Phase-A (NINMAS)

BAEC, BSMMU Campus, Dhaka.

\section{Introduction}

Social achievement of Bangladesh has superseded the economic one. It is achieved by defying various odds ranging from frequent devastating disaster to managing highly dense population, and emerging from a birth of mythical phoenix to a development puzzle. Peers including the Economist (2012) and Sen (2013) have expressed similar views. Economic development and human development does not always go hand in hand. Achievements in some goals/targets in MDGs particularly in reducing under five mortality rate, women empowerment, and poverty reduction boosted the confidence of policy makers to effectively implement sustainable development agenda. For the first time in the history of country, Bangladesh economy crossed over 7\% growth rate in 2016.

The growth rate of $7.28 \%$ that was registered in the fiscal year 2016-17 meant that Bangladesh economy has stepped into an elite group of developing countries that have been experiencing higher rate of growth. The per capita income has been increased from US\$ 1465 to US\$ $1610^{1}$.

Poverty reduction rates are $1.8 \%, 1.7 \%$ and $1.2 \%$ in 2000-2005, 2005-2010 and 2010-2016 respectively. HIES 2016 Report stated that Head Count poverty rates are $24.30 \%$ and $12.90 \%$ for upper and lower poverty line though GINI coefficient slightly deteriorated from 0.45 to 0.48. The progress on the food security have not only contributed to revitalize rural economy but also helped reduce inequality. 
Underweight children under-five years of age have come down to $32.6 \%$ (2014) from $66 \%$ (1990). The level of stunting has declined consistently from $50.6 \%$ (2004) to $36.1 \%$ (2014). Likewise wasting declined marginally to $14.3 \%$ (2014) from 14.5\% (2004). Life expectancy at birth is 71.60 years (2016), expected schooling years is 10.20 years.

Under EPI (Expanded Program on Immunization), 82.5\% children were fully vaccinated which was only $2 \%$ in 1985.

From 1982 to 2015 , the under-five mortality rate declined from 212 to 36 deaths $/ 1000$ live births. Total fertility rate is now $2.10 \%$ only (2015). Since 1990 , the primary school enrolment has increased 1.6 times. In the Global Gender Gap index 2017, Bangladesh ranked 47 out of 144 countries (WEF, 2017).

The main development strategy of the government is to accelerate GDP growth by higher investment and manufacturing sector growth. However, the growth is targeted to be pro poor and employment generation so that poverty rate can be sufficiently reduced as 2.6 million persons aged 15 or above are still unemployed.

Bangladesh is one of the most climate vulnerable countries, which affects the livelihoods of people.

One of the great concerns in export is the concentration of few items which make the export vulnerable to change in global political and economic situation. Skill development is one of the priority areas, improving which will not only Given the fact that implementation of SDGs heavily relies on building strong institutions and ensuring accountable governance, making this happen will be the ultimate challenge for Bangladesh.

Domestic investment only cannot fulfill the required investment gap to reach $8 \%$ growth by 2020 . The government initiative will be needed to establish 100 economic zones. The government will have to focus more on capacity building of institutions. In the globalized world, we have to look for building strong partnership and open door for new friendship with all ${ }^{1-5}$.

\section{Materials \& Methods}

This article is based on a review of related literature, newspaper articles and online searches using Pubmed, Google and Banglajol. Combinations of key words related to each of the subject areas were used. Websites of relevant institutions, government and nongovernmental organizations were also searched. The literature thus obtained was categorized and reviewed carefully.

\section{MDGs}

The Millennium Development Goals (MDGs) are eight goals with measurable targets and clear deadlines for improving the lives of the world's poorest people. To meet these goals and eradicate poverty, leaders of 189 countries signed the historic millennium declaration at the United Nations Millennium Summit in 2000.

MDGs: Progress of Bangladesh at a glance

MDG 1: Eradicate Extreme Poverty and Hunger

MDG 2: Achieve Universal Primary Education

MDG 3: Promoting Gender Equity and Empowering Women

MDG 4: Reduce Child Mortality

MDG 5: Improve Maternal Health

MDG 6: Combat HIV/AIDS, Malaria and other Diseases

MDG 7: Ensuring Environmental Sustainability

MDG 8: Developing a Global Partnership for Development $6,7,8$

Bangladesh MDGs Achievement:

1. Reducing Extreme Poverty

2. Reducing prevalence of underweight children under 5 years

3. Reducing under-five child mortality

4. Increasing enrolment in primary schools

5. Increased ratio of girls to boys in primary and secondary education

6. Improved maternal health ${ }^{9,10}$

\section{SDGs and SFYP}

SDG titled "Transforming Our World: The 2030 Agenda for Sustainable Development" has been now formally adopted at United Nations in September 2015, including the overarching education goal SDG 4 ("Ensure inclusive and equitable education and promote lifelong learning opportunities for all") $)^{11}$.

\section{Sustainable Development Goals and targets}

\section{Goal 1. End poverty in all its forms everywhere}

1.1 by 2030 , eradicate extreme poverty for all people everywhere, currently measured as people living on less than $\$ 1.25$ a day

1.2 by 2030 , reduce at least by half the proportion of men, women and children of all ages living in poverty in all its dimensions according to national definitions

1.3 implement nationally appropriate social protection systems and measures for all, including floors, and by 2030 achieve substantial coverage of the poor and the vulnerable

1.4 by 2030 ensure that all men and women, particularly the poor and the vulnerable, have equal rights to economic resources, as well as access to basic services, ownership, and control over land and other forms of property, inheritance, 
natural resources, appropriate new technology, and financial services including microfinance

1.5 by 2030 build the resilience of the poor and those in vulnerable situations, and reduce their exposure and vulnerability to climate-related extreme events and other economic, social and environmental shocks and disasters

1.a. ensure significant mobilization of resources from a variety of sources, including through enhanced development cooperation to provide adequate and predictable means for developing countries, in particular LDCs, to implement programmes and policies to end poverty in all its dimensions

1.b create sound policy frameworks, at national, regional and international levels, based on pro-poor and gender-sensitive development strategies to support accelerated investments in poverty eradication actions ${ }^{11}$

Goal 2. End hunger, achieve food security and improved nutrition, and promote sustainable agriculture

2.1 by 2030 end hunger and ensure access by all people, in particular the poor and people in vulnerable situations including infants, to safe, nutritious and sufficient food all year round

2.2 by 2030 end all forms of malnutrition, including achieving by 2025 the internationally agreed targets on stunting and wasting in children under five years of age, and address the nutritional needs of adolescent girls, pregnant and lactating women, and older persons.

2.3 by 2030 double the agricultural productivity and the incomes of small-scale food producers, particularly women, indigenous peoples, family farmers, pastoralists and fishers, including through secure and equal access to land, other productive resources and inputs, knowledge, financial services, markets, and opportunities for value addition and non-farm employment.

2.4 by 2030 ensure sustainable food production systems and implement resilient agricultural practices that increase productivity and production, that help maintain ecosystems, that strengthen capacity for adaptation to climate change, extreme weather, drought, flooding and other disasters, and that progressively improve land and soil quality.

2.5 by 2020 maintain genetic diversity of seeds, cultivated plants, farmed and domesticated animals and their related wild species, including through soundly managed and diversified seed and plant banks at national, regional and international levels, and ensure access to and fair and equitable sharing of benefits arising from the utilization of genetic resources and associated traditional knowledge as internationally agreed.

2.a. increase investment, including through enhanced international cooperation, in rural infrastructure, agricultural research and extension services, technology development, and plant and livestock gene banks to enhance agricultural productive capacity in developing countries, in particular in least developed countries

2.b. correct and prevent trade restrictions and distortions in world agricultural markets including by the parallel elimination of all forms of agricultural export subsidies and all export measures with equivalent effect, in accordance with the mandate of the Doha Development Round

2.c. adopt measures to ensure the proper functioning of food commodity markets and their derivatives, and facilitate timely access to market information, including on food reserves, in order to help limit extreme food price volatility ${ }^{12}$

\section{Goal 3. Ensure healthy lives and promote well-being for all at all ages}

3.1 by 2030 reduce the global maternal mortality ratio to less than 70 per 100,000 live births

3.2 by 2030 end preventable deaths of newborns and under-five children

3.3 by 2030 end the epidemics of AIDS, tuberculosis, malaria, and neglected tropical diseases and combat hepatitis, water-borne diseases, and other communicable diseases

3.4 by 2030 reduce by one-third pre-mature mortality from non-communicable diseases (NCDs) through prevention and treatment, and promote mental health and wellbeing

3.5 strengthen prevention and treatment of substance abuse, including narcotic drug abuse and harmful use of alcohol

3.6 by 2020 halve global deaths and injuries from road traffic accidents

3.7 by 2030 ensure universal access to sexual and reproductive health care services, including for family planning, information and education, and the integration of reproductive health into national strategies and programmes

3.8 achieve universal health coverage (UHC), including financial risk protection, access to quality essential health care services, and access to safe, effective, quality, and affordable essential medicines and vaccines for all

3.9 by 2030 substantially reduce the number of deaths and illnesses from hazardous chemicals and air, water, and soil pollution and contamination

3.a strengthen implementation of the Framework Convention on Tobacco Control in all countries as appropriate

3.b support research and development of vaccines and medicines for the communicable and non-communicable diseases that primarily affect developing countries, provide access toaffordable essential medicines and vaccines, in accordance with the Doha Declaration which affirms the right of developing countries to use to the full 
the provisions in the TRIPS agreement regarding flexibilities to protect public health and, in particular, provide access to medicines for all

3.c increase substantially health financing and the recruitment, development and training and retention of the health workforce in developing countries, especially in LDCs and SIDS

3.d strengthen the capacity of all countries, particularly developing countries, for early warning, risk reduction, and management of national and global health risks ${ }^{12}$

Goal 4. Ensure inclusive and equitable quality education and promote life-long learning opportunities for all

4.1 by 2030 , ensure that all girls and boys complete free, equitable and quality primary and secondary education leading to relevant and effective learning outcomes

4.2 by 2030 ensure that all girls and boys have access to quality early childhood development, care and pre-primary education so that they are ready for primary education

4.3 by 2030 ensure equal access for all women and men to affordable quality technical, vocational and tertiary education, including university

4.4 by 2030 , increase by $\mathrm{x} \%$ the number of youth and adults who have relevant skills, including technical and vocational skills, for employment, decent jobs and entrepreneurship

4.5 by 2030 , eliminate gender disparities in education and ensure equal access to all levels of education and vocational training for the vulnerable, including persons with disabilities, indigenous peoples, and children in vulnerable situationstt

4.6 by 2030 ensure that all youth and at least $\mathrm{x} \%$ of adults, both men and women, achieve literacy and numeracy

4.7 by 2030 ensure all learners acquire knowledge and skills needed to promote sustainable development, including among others through education for sustainable development and sustainable lifestyles, human rights, gender equality, promotion of a culture of peace and non-violence, global citizenship, and appreciation of cultural diversity and of cultures contribution to sustainable development

4.a build and upgrade education facilities that are child, disability and gender sensitive and provide safe, non-violent, inclusive and effective learning environments for all

4.b by 2020 expand by $\mathrm{x} \%$ globally the number of scholarships for developing countries in particular LDCs, SIDS and African countries to enrol in higher education, including vocational training, ICT, technical, engineering and scientific programmes in developed countries and other developing countries 4.c by 2030 increase by $\mathrm{x} \%$ the supply of qualified teachers, including through international cooperation for teacher training in developing countries, especially LDCs and SIDS ${ }^{13}$

\section{Goal 5. Achieve gender equality and empower all women and girls}

5.1 end all forms of discrimination against all women and girls everywhere

5.2 eliminate all forms of violence against all women and girls in public and private spheres, including trafficking and sexual and other types of exploitation

5.3 eliminate all harmful practices, such as child, early and forced marriage and female genital mutilations

5.4 recognize and value unpaid care and domestic work through the provision of public services, infrastructure and social protection policies, and the promotion of shared responsibility within the household and the family as nationally appropriate

5.5 ensure women's full and effective participation and equal opportunities for leadership at all levels of decision-making in political, economic, and public life

5.6 ensure universal access to sexual and reproductive health and reproductive rights as agreed in accordance with the Programme of Action of the ICPD and the Beijing Platform for Action and the outcome documents of their review conferences

5.a undertake reforms to give women equal rights to economic resources, as well as access to ownership and control over land and other forms of property, financial services, inheritance, and natural resources in accordance with national laws

5.b enhance the use of enabling technologies, in particular ICT, to promote women's empowerment

5.c adopt and strengthen sound policies and enforceable legislation for the promotion of gender equality and the empowerment of all women and girls at all levels ${ }^{14}$

Goal 6. Ensure availability and sustainable management of water and sanitation for all

6.1 by 2030 , achieve universal and equitable access to safe and affordable drinking water for all

6.2 by 2030 , achieve access to adequate and equitable sanitation and hygiene for all, and end open defecation, paying special attention to the needs of women and girls and those in vulnerable situations

6.3 by 2030 , improve water quality by reducing pollution, eliminating dumping and minimizing release of hazardous chemicals and materials, halving the proportion of untreated wastewater, and increasing recycling and safe reuse by $\mathrm{x} \%$ globally 
6.4 by 2030 , substantially increase water-use efficiency across all sectors and ensure sustainable withdrawals and supply of freshwater to address water scarcity, and substantially reduce the number of people suffering from water scarcity

6.5 by 2030 implement integrated water resources management at all levels, including through transboundary cooperation as appropriate

6.6 by 2020 protect and restore water-related ecosystems, including mountains, forests, wetlands, rivers, aquifers and lakes

6.a by 2030, expand international cooperation and capacity-building support to developing countries in water and sanitation related activities and programmes, including water harvesting, desalination, water efficiency, wastewater treatment, recycling and reuse technologies

6.b support and strengthen the participation of local communities for improving water and sanitation management 14

Goal 7. Ensure access to affordable, reliable, sustainable, and modern energy for all

7.1 by 2030 ensure universal access to affordable, reliable, and modern energy services

7.2 increase substantially the share of renewable energy in the global energy mix by 2030

7.3 double the global rate of improvement in energy efficiency by 2030

7.a by 2030 enhance international cooperation to facilitate access to clean energy research and technologies, including renewable energy, energy efficiency, and advanced and cleaner fossil fuel technologies, and promote investment in energy infrastructure and clean energy technologies

7.b by 2030 expand infrastructure and upgrade technology for supplying modern and sustainable energy services for all in developing countries, particularly LDCs and SIDS ${ }^{14}$

Goal 8. Promote sustained, inclusive and sustainable economic growth, full and productive employment and decent work for all

8.1 sustain per capita economic growth in accordance with national circumstances, and in particular at least $7 \%$ per annum GDP growth in the least-developed countries

8.2 achieve higher levels of productivity of economies through diversification, technological upgrading and innovation, including through a focus on high value added and labour-intensive sectors

8.3 promote development-oriented policies that support productive activities, decent job creation, entrepreneurship, creativity and innovation, and encourage formalization and growth of micro-, small- and medium-sized enterprises including through access to financial services
8.4 improve progressively through 2030 global resource efficiency in consumption and production, and endeavour to decouple economic growth from environmental degradation in accordance with the 10-year framework of programmes on sustainable consumption and production with developed countries taking the lead

8.5 by 2030 achieve full and productive employment and decent work for all women and men, including for young people and persons with disabilities, and equal pay for work of equal value

8.6 by 2020 substantially reduce the proportion of youth not in employment, education or training

8.7 take immediate and effective measures to secure the prohibition and elimination of the worst forms of child labour, eradicate forced labour, and by 2025 end child labour in all its forms including recruitment and use of child soldiers

8.8 protect labour rights and promote safe and secure working environments of all workers, including migrant workers, particularly women migrants, and those in precarious employment

8.9 by 2030 devise and implement policies to promote sustainable tourism which creates jobs, promotes local culture and products

8.10 strengthen the capacity of domestic financial institutions to encourage and to expand access to banking, insurance and financial services for all

8.a increase Aid for Trade support for developing countries, particularly LDCs, including through the Enhanced Integrated Framework for LDCs

8 .b by 2020 develop and operationalize a global strategy for youth employment and implement the ILO Global Jobs Pact ${ }^{14}$

Goal 9. Build resilient infrastructure, promote inclusive and sustainable industrialization and foster innovation

9.1 develop quality, reliable, sustainable and resilient infrastructure, including regional and trans-border infrastructure, to support economic development and human well-being, with a focus on affordable and equitable access for all

9.2 promote inclusive and sustainable industrialization, and by 2030 raise significantly industry's share of employment and GDP in line with national circumstances, and double its share in LDCs

9.3 increase the access of small-scale industrial and other enterprises, particularly in developing countries, to financial services including affordable credit and their integration into value chains and markets

9.4 by 2030 upgrade infrastructure and retrofit industries to make them sustainable, with increased resource use efficiency and greater adoption of clean and 
environmentally sound technologies and industrial processes, all countries taking action in accordance with their respective capabilities

9.5 enhance scientific research, upgrade the technological capabilities of industrial sectors in all countries, particularly developing countries, including by 2030 encouraging innovation and increasing the number of R\&D workers per one million people by $\mathrm{x} \%$ and public and private $R \& D$ spending

9.a facilitate sustainable and resilient infrastructure development in developing countries through enhanced financial, technological and technical support to African countries, LDCs, LLDCs and SIDS

9.b support domestic technology development, research and innovation in developing countries including by ensuring a conducive policy environment for inter alia industrial diversification and value addition to commodities

9.c significantly increase access to ICT and strive to provide universal and affordable access to internet in LDCs by $2020^{14}$

\section{Goal 10. Reduce inequality within and among countries}

10.1 by 2030 progressively achieve and sustain income growth of the bottom $40 \%$ of the population at a rate higher than the national average

10.2 by 2030 empower and promote the social, economic and political inclusion of all irrespective of age, sex, disability, race, ethnicity, origin, religion or economic or other status

10.3 ensure equal opportunity and reduce inequalities of outcome, including through eliminating discriminatory laws, policies and practices and promoting appropriate legislation, policies and actions in this regard

10.4 adopt policies especially fiscal, wage, and social protection policies and progressively achieve greater equality

10.5 improve regulation and monitoring of global financial markets and institutions and strengthen implementation of such regulations

10.6 ensure enhanced representation and voice of developing countries in decision making in global international economic and financial institutions in order to deliver more effective, credible, accountable and legitimate institutions

10.7 facilitate orderly, safe, regular and responsible migration and mobility of people, including through implementation of planned and well-managed migration policies

10.a implement the principle of special and differential treatment for developing countries, in particular least developed countries, in accordance with WTO agreements 10.b encourage ODA and financial flows, including foreign direct investment, to states where the need is greatest, in particular LDCs, African countries, SIDS, and LLDCs, in accordance with their national plans and programmes

10.c by 2030 , reduce to less than $3 \%$ the transaction costs of migrant remittances and eliminate remittance corridors with costs higher than $5 \%$

Goal 11. Make cities and human settlements inclusive, safe, resilient and sustainable

11.1 by 2030 , ensure access for all to adequate, safe and affordable housing and basic services, and upgrade slums

11.2 by 2030 , provide access to safe, affordable, accessible and sustainable transport systems for all, improving road safety, notably by expanding public transport, with special attention to the needs of those in vulnerable situations, women, children, persons with disabilities and older persons

11.3 by 2030 enhance inclusive and sustainable urbanization and capacities for participatory, integrated and sustainable human settlement planning and management in all countries

11.4 strengthen efforts to protect and safeguard the world's cultural and natural heritage

11.5 by 2030 significantly reduce the number of deaths and the number of affected people and decrease by $\mathrm{y} \%$ the economic losses relative to GDP caused by disasters, including water-related disasters, with the focus on protecting the poor and people in vulnerable situations

11.6 by 2030 , reduce the adverse per capita environmental impact of cities, including by paying special attention to air quality, municipal and other waste management

11.7 by 2030 , provide universal access to safe, inclusive and accessible, green and public spaces, particularly for women and children, older persons and persons with disabilities

11.a support positive economic, social and environmental links between urban, peri-urban and rural areas by strengthening national and regional development planning

$11 . b$ by 2020 , increase by $\mathrm{x} \%$ the number of cities and human settlements adopting and implementing integrated policies and plans towards inclusion, resource efficiency, mitigation and adaptation to climate change, resilience to disasters, develop and implement in line with the forthcoming Hyogo Framework holistic disaster risk management at all levels

11.c support least developed countries, including through financial and technical assistance, for sustainable and resilient buildings utilizing local materials ${ }^{15}$ 
Goal 12. Ensure sustainable consumption and production patterns

12.1 implement the 10-Year Framework of Programmes on sustainable consumption and production (10YFP), all countries taking action, with developed countries taking the lead, taking into account the development and capabilities of developing countries

12.2 by 2030 achieve sustainable management and efficient use of natural resources

12.3 by 2030 halve per capita global food waste at the retail and consumer level, and reduce food losses along production and supply chains including post-harvest losses

12.4 by 2020 achieve environmentally sound management of chemicals and all wastes throughout their life cycle in accordance with agreed international frameworks and significantly reduce their release to air, water and soil to minimize their adverse impacts on human health and the environment

12.5 by 2030 , substantially reduce waste generation through prevention, reduction, recycling, and reuse

12.6 encourage companies, especially large and trans-national companies, to adopt sustainable practices and to integrate sustainability information into their reporting cycle

12.7 promote public procurement practices that are sustainable in accordance with national policies and priorities

12.8 by 2030 ensure that people everywhere have the relevant information and awareness for sustainable development and lifestyles in harmony with nature

12.a support developing countries to strengthen their scientific and technological capacities to move towards more sustainable patterns of consumption and production

12.b develop and implement tools to monitor sustainable development impacts for sustainable tourism which creates jobs, promotes local culture and products

12.c rationalize inefficient fossil fuel subsidies that encourage wasteful consumption by removing marketdistortions, in accordance with national circumstances, including by restructuring taxation and phasing out those harmful subsidies, where they exist, to reflect their environmental impacts, taking fully into account the specific needs and conditions of developing countries and minimizing the possible adverse impacts on their development in a manner that protects the poor and the affected communities ${ }^{16}$

Goal 13. Take urgent action to combat climate change and its impacts *

*Acknowledging that the UNFCCC is the primary international, intergovernmental forum for negotiating the global response to climate change
13.1 strengthen resilience and adaptive capacity to climate related hazards and natural disasters in all countries

13.2 integrate climate change measures into national policies, strategies, and planning

13.3 improve education, awareness raising and human and institutional capacity on climate change mitigation, adaptation, impact reduction, and early warning

13.a implement the commitment undertaken by developed country Parties to the UNFCCC to a goal of mobilizing jointly USD100 billion annually by 2020 from all sources to address the needs of developing countries in the context of meaningful mitigation actions and transparency on implementation and fully operationalize the Green Climate Fund through its capitalization as soon as possible

13.b Promote mechanisms for raising capacities for effective climate change related planning and management, in LDCs, including focusing on women, youth, local and marginalized communities 16

Goal 14. Conserve and sustainably use the oceans, seas and marine resources for sustainable development

14.1 by 2025 , prevent and significantly reduce marine pollution of all kinds, particularly from land-based activities, including marine debris and nutrient pollution

14.2 by 2020 , sustainably manage and protect marine and coastal ecosystems to avoid significant adverse impacts, including by strengthening their resilience, and take action for their restoration, to achieve healthy and productive oceans

14.3 minimize and address the impacts of ocean acidification, including through enhanced scientific cooperation at all levels

14.4 by 2020 , effectively regulate harvesting, and end overfishing, illegal, unreported and unregulated (IUU) fishing and destructive fishing practices and implement science-based management plans, to restore fish stocks in the shortest time feasible at least to levels that can produce maximum sustainable yield as determined by their biological characteristics

14.5 by 2020 , conserve at least 10 per cent of coastal and marine areas, consistent with national and international law and based on best available scientific information

14.6 by 2020 , prohibit certain forms of fisheries subsidies which contribute to overcapacity and overfishing, and eliminate subsidies that contribute to IUU fishing, and refrain from introducing new such subsidies, recognizing that appropriate and effective special and differential treatment for developing and least developed countries should be an integral part of the WTO fisheries subsidies negotiation *

14.7 by 2030 increase the economic benefits to SIDS and LDCs from the sustainable use of marine resources, including through sustainable management of fisheries, aquaculture and tourism 
14.a increase scientific knowledge, develop research capacities and transfer marine technology taking into account the Intergovernmental Oceanographic Commission Criteria and Guidelines on the Transfer of Marine Technology, in order to improve ocean health and to enhance the contribution of marine biodiversity to the development of developing countries, in particular SIDS and LDCs

14.b provide access of small-scale artisanal fishers to marine resources and markets

14.c ensure the full implementation of international law, as reflected in UNCLOS for states parties to it, including, where applicable, existing regional and international regimes for the conservation and sustainable use of oceans and their resources by their parties ${ }^{16}$

Goal 15. Protect, restore and promote sustainable use of terrestrial ecosystems, sustainably manage forests, combat desertification, and halt and reverse land degradation and halt biodiversity loss

15.1 by 2020 ensure conservation, restoration and sustainable use of terrestrial and inland freshwater ecosystems and their services, in particular forests, wetlands, mountains and drylands, in line with obligations under international agreements

15.2 by 2020 , promote the implementation of sustainable management of all types of forests, halt deforestation, restore degraded forests, and increase afforestation and reforestation by $\mathrm{x} \%$ globally

15.3 by 2020 , combat desertification, and restore degraded land and soil, including land affected by desertification, drought and floods, and strive to achieve a land-degradation neutral world

15.4 by 2030 ensure the conservation of mountain ecosystems, including their biodiversity, to enhance their capacity to provide benefits which are essential for sustainable development

15.5 take urgent and significant action to reduce degradation of natural habitat, halt the loss of biodiversity, and by 2020 protect and prevent the extinction of threatened species

15.c enhance global support to efforts to combat poaching and trafficking of protected species, including by increasing the capacity of local communities to pursue sustainable livelihood opportunities ${ }^{16}$

Goal 16. Promote peaceful and inclusive societies for sustainable development, provide access to justice for all and build effective, accountable and inclusive institutions at all levels

16.1 significantly reduce all forms of violence and related death rates everywhere

16.2 end abuse, exploitation, trafficking and all forms of violence and torture against children
16.3 promote the rule of law at the national and international levels, and ensure equal access to justice for all

16.4 by 2030 significantly reduce illicit financial and arms flows, strengthen recovery and return of stolen assets, and combat all forms of organized crime

16.5 substantially reduce corruption and bribery in all its forms

16.6 develop effective, accountable and transparent institutions at all levels

16.7 ensure responsive, inclusive, participatory and representative decision-making at all levels

16.8 broaden and strengthen the participation of developing countries in the institutions of global governance

16.9 by 2030 provide legal identity for all including birth registration

16.10 ensure public access to information and protect fundamental freedoms, in accordance with national legislation and international agreements

16.a strengthen relevant national institutions, including through international cooperation, for building capacities at all levels, in particular in developing countries, for preventing violence and combating terrorism and crime

16.b promote and enforce non-discriminatory laws and policies for sustainable development ${ }^{16}$

Goal 17. Strengthen the means of implementation and revitalize the global partnership for sustainable development

\section{Finance}

17.1 strengthen domestic resource mobilization, including through international support to developing countries to improve domestic capacity for tax and other revenue collection

17.2 developed countries to implement fully their ODA commitments, including to provide $0.7 \%$ of GNI in ODA to developing countries of which $0.15-0.20 \%$ to least-developed countries

17.3 mobilize additional financial resources for developing countries from multiple sources

17.4 assist developing countries in attaining long-term debt sustainability through coordinated policies aimed at fostering debt financing, debt relief and debt restructuring, as appropriate, and address the external debt of highly indebted poor countries (HIPC) to reduce debt distress

17.5 adopt and implement investment promotion regimes for LDCs 


\section{Technology}

17.6 enhance North-South, South-South and triangular regional and international cooperation on and access to science, technology and innovation, and enhance knowledge sharing on mutually agreed terms, including through improved coordination among existing mechanisms, particularly at UN level, and through a global technology facilitation mechanism when agreed

17.7 promote development, transfer, dissemination and diffusion of environmentally sound technologies to developing countries on favourable terms, including on concessional and preferential terms, as mutually agreed

17.8 fully operationalize the Technology Bank and STI (Science, Technology and Innovation) capacity building mechanism for LDCs by 2017, and enhance the use of enabling technologies in particular ICT ${ }^{17}$

\section{Capacity building}

17.9 enhance international support for implementing effective and targeted capacity building in developing countries to support national plans to implement all sustainable development goals, including through North-South, South-South, and triangular cooperation Trade

17.10 promote a universal, rules-based, open, non-discriminatory and equitable multilateral trading system under the WTO including through the conclusion of negotiations within its Doha Development Agenda

17.11 increase significantly the exports of developing countries, in particular with a view to doubling the LDC share of global exports by 2020

17.12 realize timely implementation of duty-free, quota-free market access on a lasting basis for all least developed countries consistent with WTO decisions, including through ensuring that preferential rules of origin applicable to imports from LDCs are transparent and simple, and contribute to facilitating market access ${ }^{17}$

\section{Systemic issues}

\section{Policy and institutional coherence}

17.13 enhance global macroeconomic stability including through policy coordination and policy coherence

17.14 enhance policy coherence for sustainable development

17.15 respect each country's policy space and leadership to establish and implement policies for poverty eradication and sustainable development ${ }^{17}$

\section{Multi-stakeholder partnerships}

17.16 enhance the global partnership for sustainable development complemented by multi-stakeholder partnerships that mobilize and share knowledge, expertise, technologies and financial resources to support the achievement of sustainable development goals in all countries, particularly developing countries
17.17 encourage and promote effective public, public-private, and civil society partnerships, building on the experience and resourcing strategies of partnerships ${ }^{17}$

\section{Data, monitoring and accountability}

17.18 by 2020 , enhance capacity building support to developing countries, including for LDCs and SIDS, to increase significantly the availability of high-quality, timely and reliable data disaggregated by income, gender, age, race, ethnicity, migratory status, disability, geographic location and other characteristics relevant in national contexts

17.19 by 2030 , build on existing initiatives to develop measurements of progress on sustainable development that complement GDP, and support statistical capacity building in developing countries ${ }^{17}$.

\section{MDG: GOAL WISE ACHIEVEMENT}

GOAL 1 : Bangladesh has made commendable progress in respect of eradication of poverty and hunger. It has sustained a GDP growth rate in excess of 6 percent in recent years that has played a positive role in eradicating poverty. The robust growth has been accompanied by corresponding improvements in several social indicators such as increased life expectancy and lower fertility rate despite having one of the world's highest population densities (Table I).

Table-I: Eradicate Extreme Poverty and Hunger.

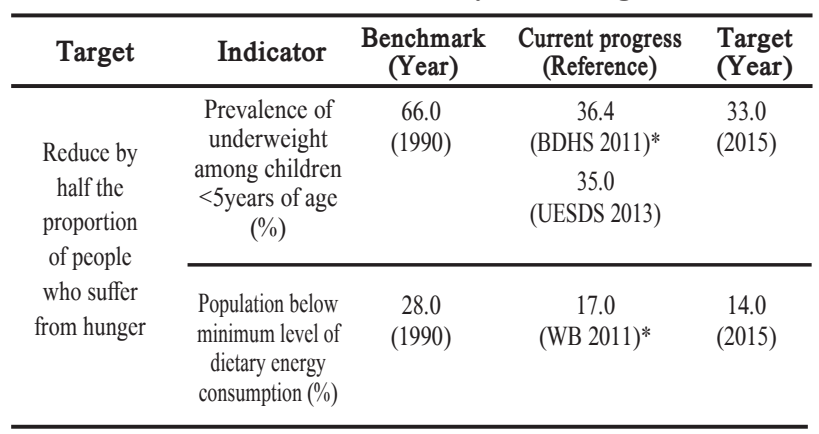

GOAL 2 : Achieve Universal Primary Education

Significant progress has been made in increasing equitable access in education (NER: 98.7 percent; girls: 99.4 percent, boys: 97.2 percent), reduction of dropouts, improvement in completion of the cycle, and implementation of a number of quality enhancement measures in primary education. Bangladesh has already achieved gender parity in primary and secondary enrolment.

\section{GOAL 3 : Promote Gender Equality and Empower Women}

Bangladesh has already achieved this goal i.e. gender parity in primary and secondary education at the national level. This positive development has occurred due to some specific public interventions focusing on girl students, such as stipends and exemption of tuition fees for girls in rural areas, and the stipend scheme for girls at the secondary level. Bangladesh has made significant progress in promoting the objectives of ensuring gender equality and empowerment of women. 
GOAL 4 : Bangladesh is on track in meeting the target of this goal measured in three different indicators like under-five mortality rate, infant mortality rate and immunization against measles (Table II).

Table-II: Reduce Child Mortality.

\begin{tabular}{|c|c|c|c|c|}
\hline Target & Indicator & $\begin{array}{c}\text { Benchmark } \\
\text { (Year) }\end{array}$ & $\begin{array}{l}\text { Current progress } \\
\text { (Reference) }\end{array}$ & $\begin{array}{l}\text { Target } \\
\text { (Year) }\end{array}$ \\
\hline \multirow{3}{*}{$\begin{array}{l}\text { Reduce by } \\
\text { two-thirds } \\
\text { the } \\
\text { mortality } \\
\text { rate among } \\
\text { under-five } \\
\text { children }\end{array}$} & $\begin{array}{c}\text { Death rate } \\
\text { among } \\
\text { under-five } \\
\text { children/1,000 } \\
\text { live births }\end{array}$ & $\begin{array}{c}144.0 \\
(1990) \\
144.0 \\
(1990)\end{array}$ & $\begin{array}{l}41.0(\text { UN 2013)** } \\
44.0 \text { (SVRS 2011) } \\
53.0(\text { BDHS 2011) }\end{array}$ & $\begin{array}{c}48.0 \\
(2015)\end{array}$ \\
\hline & $\begin{array}{l}\text { Infant mortality } \\
\text { rate } / 1,000 \text { live } \\
\text { births }\end{array}$ & $\begin{array}{c}94.0 \\
(1990)\end{array}$ & $\begin{array}{c}33.0(\text { UN } 2013)^{*} \\
35.0(\text { SVRS 2011) } \\
43.0(\text { BDHS 2011) }\end{array}$ & $\begin{array}{c}31.3 \\
(2015)\end{array}$ \\
\hline & $\begin{array}{l}\text { 1-year old children } \\
\text { immunized } \\
\text { against measles } \\
(\%)\end{array}$ & $\begin{array}{c}52.0 \\
(1991)\end{array}$ & $\begin{array}{c}85.5 \% \\
(\text { BECES 2012)* } \\
87.5 \\
\text { (BDHS 2011) }\end{array}$ & $\begin{array}{l}100.0 \\
(2015)\end{array}$ \\
\hline
\end{tabular}

GOAL 5: According to Bangladesh Maternal Mortality Survey (BMMS), maternal mortality declined from 322 in 2001 to 194 in 2010, a 40 percent decline in nine years. The average rate of decline from the base year has been about 3.3 percent per year, compared with the average annual rate of reduction of 3.0 percent required for achieving the MDG in 2015 (Table III). Table-III: Improve Maternal Health.

\begin{tabular}{|c|c|c|c|c|}
\hline Target & Indicator & $\begin{array}{c}\text { Benchmark } \\
\text { (Year) }\end{array}$ & $\begin{array}{l}\text { Current progress } \\
\text { (Reference) }\end{array}$ & $\begin{array}{l}\text { Target } \\
\text { (Year) }\end{array}$ \\
\hline \multirow{2}{*}{$\begin{array}{l}\text { Reduce by } \\
\text { three-quarters } \\
\text { the maternal } \\
\text { mortality } \\
\text { ratio }\end{array}$} & $\begin{array}{c}\text { Maternal } \\
\text { mortality } \\
\text { ratio/100,000 } \\
\text { livebirths }\end{array}$ & $\begin{array}{c}574.0 \\
(1990)\end{array}$ & 170.00 (UN 2013)* & $\begin{array}{l}143.5 \\
(2015)\end{array}$ \\
\hline & $\begin{array}{c}\text { Births } \\
\text { attended by } \\
\text { skilled health } \\
\text { personnel } \\
(\%)\end{array}$ & $\begin{array}{c}7.0 \\
(1990)\end{array}$ & $\begin{array}{c}26.5 \\
(\text { BMMS 2010) } \\
43.5 \\
\text { (MICS 2012-2013) }\end{array}$ & $\begin{array}{c}50.0 \\
(2015)\end{array}$ \\
\hline \multirow{5}{*}{$\begin{array}{l}\text { Ensure, by } \\
\text { 2015, universal } \\
\text { access to } \\
\text { reproductive } \\
\text { healthcare }\end{array}$} & $\begin{array}{l}\text { Contraceptive } \\
\text { prevalence } \\
\text { rate }(\%)\end{array}$ & $\begin{array}{c}39.9 \\
(1991)\end{array}$ & $\begin{array}{c}61.2 \\
(\text { BDHS 2011)* } \\
61.8 \\
\text { (MICS 2012-2013) }\end{array}$ & $\begin{array}{c}72.0 \\
(2016)\end{array}$ \\
\hline & $\begin{array}{c}\text { Births rate } \\
\text { among } \\
\text { adolescent } \\
\text { mothers } 1,000 \\
\text { women } \\
\end{array}$ & $\begin{array}{c}39.9 \\
(1991)\end{array}$ & $\begin{array}{c}105.0 \\
(\text { BMMS 2010) } \\
83.0 \\
\text { (MICS 2012-2013) }\end{array}$ & $\begin{array}{c}77.0 \\
(1990-91)\end{array}$ \\
\hline & $\begin{array}{c}\text { Antenatal care } \\
\text { coverage (at } \\
\text { least one visit } \\
\text { by skilled } \\
\text { health } \\
\text { professional) } \\
(\%)\end{array}$ & $\begin{array}{c}27.5 \\
(1993)\end{array}$ & $\begin{array}{c}54.6 \\
\text { (BDHS 2011) } \\
58.7 \\
\text { (MICS 2012-2013) }\end{array}$ & $\begin{array}{l}100.0 \\
(2015)\end{array}$ \\
\hline & $\begin{array}{c}\text { Antenatal care } \\
\text { coverage (at } \\
\text { least four } \\
\text { visits) }(\%)\end{array}$ & $\begin{array}{c}05.5 \\
(1993)\end{array}$ & $\begin{array}{c}25.5 \\
\text { (BDHS 2011) } \\
24.7 \\
\text { (MICS 2012-2013) }\end{array}$ & $\begin{array}{l}100.0 \\
(2015)\end{array}$ \\
\hline & $\begin{array}{l}\text { Unmet need } \\
\text { for family } \\
\text { planning }(\%)\end{array}$ & $\begin{array}{c}19.4 \\
(1993)\end{array}$ & $\begin{array}{c}13.5 \\
\text { (BDHS 2011) } \\
13.9 \\
\text { (MICS 2012-2013) }\end{array}$ & $\begin{array}{c}7.6 \\
(2016)\end{array}$ \\
\hline
\end{tabular}

GOAL 6 : Bangladesh has performed well in halting communicable diseases under this goal. Available data show that the prevalence of HIV/AIDS in Bangladesh currently is less than 0.1 percent and thus is still below an epidemic level (Table IV).

Table-IV: Combat HIV/AIDS, Malaria and Other Diseases.

\begin{tabular}{|c|c|c|c|c|}
\hline Target & Indicator & $\begin{array}{c}\text { Benchmark } \\
\text { (Year) }\end{array}$ & $\begin{array}{l}\text { Current progress } \\
\text { (Reference) }\end{array}$ & $\begin{array}{l}\text { Target } \\
\text { (Year) }\end{array}$ \\
\hline $\begin{array}{l}\text { Healt and } \\
\text { begin to } \\
\text { reberse the } \\
\text { spread of } \\
\text { HIV/AIDS }\end{array}$ & $\begin{array}{l}\text { HIV prevalence } \\
\text { among } \\
\text { population aged } \\
15-24 \text { years }(\%)\end{array}$ & $\begin{array}{c}0.005 \\
(1990)\end{array}$ & $\begin{array}{c}0.7 \% \\
(\text { NASP 2011)* }\end{array}$ & $\begin{array}{l}\text { Halt } \\
(2015)\end{array}$ \\
\hline $\begin{array}{l}\text { Ensure, by } \\
2010, \text { universal } \\
\text { success to } \\
\text { treatment for } \\
\text { HIV/ AIDS for } \\
\text { all those who } \\
\text { need }\end{array}$ & $\begin{array}{l}\text { Population with } \\
\text { advanced HIV } \\
\text { infection with } \\
\text { access to ARV } \\
\text { drugs }(\%)\end{array}$ & - & $\begin{array}{c}45.0 \\
\text { (UNGASS 2012) }\end{array}$ & $\begin{array}{l}100.0 \\
(2015)\end{array}$ \\
\hline \multirow[t]{8}{*}{$\begin{array}{l}\text { Halt and begin } \\
\text { to reverse the } \\
\text { incidence of } \\
\text { malaria and } \\
\text { other major } \\
\text { diseases }\end{array}$} & $\begin{array}{c}\text { Malarial } \\
\text { preva- } \\
\text { lence/100,000 } \\
\text { population }\end{array}$ & $\begin{array}{c}58.5 \\
(2008)\end{array}$ & $\begin{array}{c}18.4 \\
(\text { DGHS 2012)** } \\
\text { Estimated based } \\
\text { on reported } \\
\text { malaria cases }\end{array}$ & $\begin{array}{l}29.3 \\
(2015)\end{array}$ \\
\hline & $\begin{array}{l}\text { Malarial death } \\
\text { rate } / 100,000 \\
\text { population }\end{array}$ & $\begin{array}{c}0.106 \\
(2008)\end{array}$ & $\begin{array}{c}0.007 \\
\text { (DGHS 2012)** } \\
\text { Estimated based on } \\
\text { reported malaria cases }\end{array}$ & $\begin{array}{l}0.053 \\
(2015)\end{array}$ \\
\hline & $\begin{array}{c}\text { Under-five } \\
\text { children } \\
\text { sleeping under } \\
\text { insecti- } \\
\text { cide-treated } \\
\text { bednets in } \\
\text { endemic areas } \\
(\%) \\
\end{array}$ & $\begin{array}{c}81.0 \\
(2008)\end{array}$ & $\begin{array}{c}94.4 \\
(\text { DGHS 2012)** }\end{array}$ & $\begin{array}{l}90.0 \\
(2015)\end{array}$ \\
\hline & $\begin{array}{c}\text { Under-five } \\
\text { children with } \\
\text { fever treated } \\
\text { with } \\
\text { appropriate } \\
\text { antimalarial } \\
\text { drugs }(\%)\end{array}$ & $\begin{array}{c}60.0 \\
(2008)\end{array}$ & $\begin{array}{c}89.0 \\
(\text { DGHS 2011)* }\end{array}$ & $\begin{array}{l}90.0 \\
(2015)\end{array}$ \\
\hline & $\begin{array}{l}\text { TB (all forms) } \\
\text { prevalence } \\
\text { rate/100,000 } \\
\text { population }\end{array}$ & $\begin{array}{c}639.0 \\
(1990)\end{array}$ & $\begin{array}{c}411.0 \\
(\text { DGHS 2011)* }\end{array}$ & $\begin{array}{l}320.0 \\
(2015)\end{array}$ \\
\hline & $\begin{array}{l}\text { TB death } \\
\text { rate/100,000 } \\
\text { population }\end{array}$ & $\begin{array}{c}76.0 \\
(1990)\end{array}$ & $\begin{array}{c}45.0 \\
(\text { DGHS 2011)* }\end{array}$ & $\begin{array}{c}38.0 \\
(2015)\end{array}$ \\
\hline & $\begin{array}{c}\text { New smear+ve } \\
\text { TB case } \\
\text { notification rate } \\
\text { under DOTS } \\
(\%)\end{array}$ & $\begin{array}{c}21.0 \\
(1994)\end{array}$ & $\begin{array}{c}68.0 \\
(\text { DGHS 2013)** }\end{array}$ & $\begin{array}{l}>70.0 \\
(2015)\end{array}$ \\
\hline & $\begin{array}{c}\text { TB cure rate } \\
(\%) \text { with DOTS }\end{array}$ & $\begin{array}{c}73.0 \\
(1994)\end{array}$ & $\begin{array}{c}92.0 \\
(\mathrm{NTP} 2012)^{* *}\end{array}$ & $\begin{array}{l}>85.0 \\
(2015)\end{array}$ \\
\hline
\end{tabular}

GOAL 7 : At present there is only 13.20 percent of land in Bangladesh having tree cover with density of 30 percent and above and the area having tree cover is much lower than the target set for 2015. Since 1991, there has been a steady increase in $\mathrm{CO} 2$ emission in Bangladesh because of increasing development interventions and activities. In 2012, the emission was 0.32 tonne per capita (Table V). 
Table-V: Ensure Environmental Sustainabilityses.

\begin{tabular}{|c|c|c|c|c|}
\hline Target & Indicator & $\begin{array}{l}\text { Benchmark } \\
\text { (Year) }\end{array}$ & $\begin{array}{l}\text { Current progress } \\
\text { (Reference) }\end{array}$ & $\begin{array}{l}\text { Terget } \\
\text { (Year) }\end{array}$ \\
\hline $\begin{array}{c}\text { Reduce by half } \\
\text { the percentage } \\
\text { of people } \\
\text { without }\end{array}$ & $\begin{array}{c}\text { Population } \\
\text { using improved } \\
\text { drinking-water } \\
\text { sources (\%) }\end{array}$ & $78.0(1990)$ & $\begin{array}{c}98.2(\text { SVRS 2011)* } \\
97.9(\mathrm{MICS} \\
2012-2013)^{*}\end{array}$ & $\begin{array}{l}100.0 \\
(2015)\end{array}$ \\
\hline $\begin{array}{l}\text { access to safe } \\
\text { drinking-water } \\
\text { and basic } \\
\text { sanitation (\%) }\end{array}$ & $\begin{array}{c}\text { Population } \\
\text { using improved } \\
\text { sanitation } \\
\text { facility }(\%)\end{array}$ & $39.2(2006)$ & $\begin{array}{c}55.9(\mathrm{MICS} \\
2012-2013)^{*} \\
63.6(\text { SVRS } 2011)\end{array}$ & $\begin{array}{l}100.0 \\
(2015)\end{array}$ \\
\hline
\end{tabular}

GOAL 8 : Develop a Global Partnership for Development During the last two decades and more, Bangladesh, on an average, got US\$ 1,672 million ODA per year. The disbursed ODA as a proportion of Bangladesh's GDP has declined from 5.59 percent in FY 90-91 to 1.87 percent in FY 12-13, implying yearly average of 2.62 percent. During the same period, per capita ODA disbursement saw fluctuating figures ranging from US\$ 18.29 to US\$ 7.64; meaning yearly average of US\$ 12.68 . From FY 90-91 to FY12-13, on an average, each year Bangladesh got US\$ 633 million as grants and US\$ 1,045 million as loans ${ }^{18,19}$.

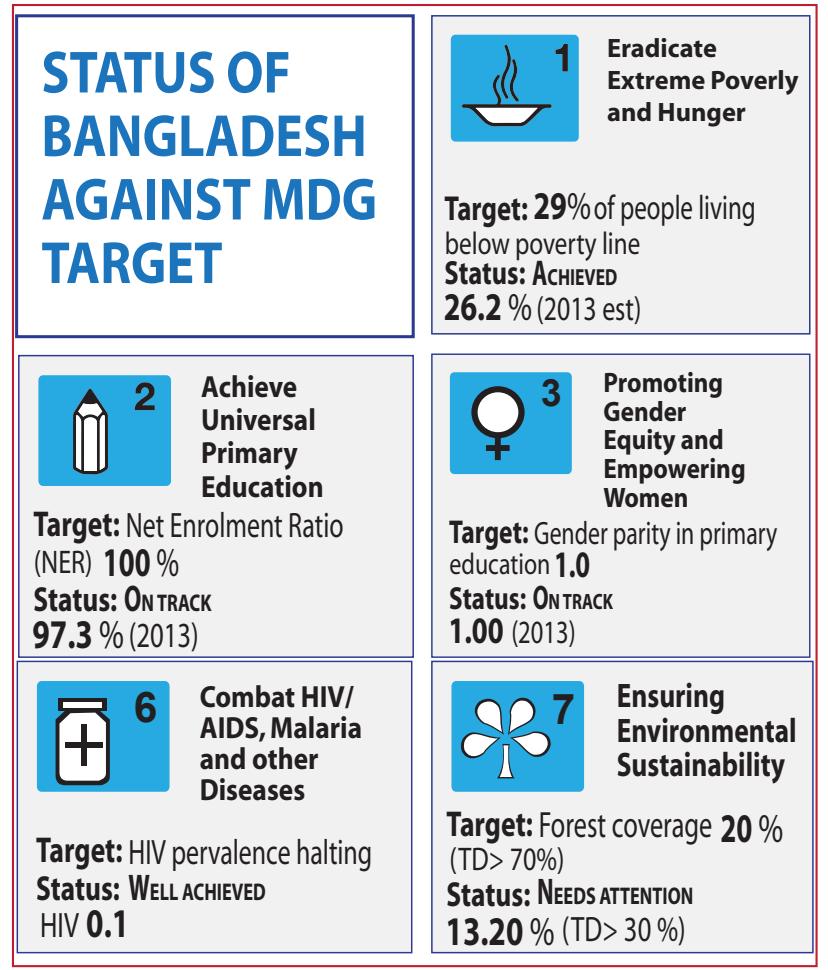

\section{Developing a Global Partnarship for Lillell|l Development}

Target: Develop further an open, rule based, predicable, non-discriminatory trading \& financial system.

Status: Needs attention

Net ODA received US\$2,871 $\mathrm{m}$ (2013)

Debt Service $\mathbf{8 . 5 8} \%$

\section{Challenges}

- Limited land for food production

- High population density

- Growing population

- Just 1 in 6 women employed in non-agricultural sector

- Protein and micronutrient deficiencies cause mateernal and child malnutrition

\section{Major misses}

- Literacy

- Employment

- Environment

Bangladesh's implementation of the 2030 Agenda

Bangladesh's journey towards the implementation of SDGs started by integrating Sustainable Development Goals (SDGs) into the 7th Five Year Plan (20162020). In this sense, Bangladesh can be called the early starter in implementation of SDGs. To spearhead the process, SDGs Implementation and Monitoring Committee has been formed at the Prime Minister's Office to facilitate the implementation of SDGs Action Plan. The General Economics Division (GED) of the Planning Commission serves as the focal point of the government for formulating SDGs implementation strategy and action plan for Poverty eradication ${ }^{20}$.

Whole of Society Approach in engaging all Stakeholders

Unlike the MDGs, SDGs are much broader all-encompassing development agenda. Therefore, it would be difficult for the public sector alone to achieve its objectives. In recognition of this fact, the government of Bangladesh has adopted a "whole of society" approach for implementation and attainment of the SDGs. As part of this, several consultations were held on stakeholders' engagement on the SDGs implementation involving the Parliamentarians, NGOs, CSOs, Business community, Development Partners, Ethnic Minorities, professional, groups, labour associations, women network and media ${ }^{20}$.

Mapping of Targets in the Implementation of SDGs Aligning with 7th FYP (2016-2020)

Bangladesh has successfully completed the "Mapping of Ministries/Divisions by Targets in the Implementation of SDGs Aligning with 7th FYP (2016-2020)", a first formal document towards implementation of the SDGs in Bangladesh and media ${ }^{21}$.

\section{Date Gap Analysis for SDGs: Bangladesh Perspective}

The govrtnment underlook a comprehensive study of data gap analysis for SDGs monitoring in Bangladesh. The study report titled "Data Gap Analysis for Sustainable Development Goals (SDGs): Bangladesh Perspective", found that Bangladesh was facing a "considerable" data gap for monitoring the SDGs as data of less than one-third of the indicators are readily available while two thirds are either partially available or not available at all. Out of total 241 indicators (for some with repeated use) to monitor against the 169 targets, data of only 70 indicators are readily available while data on 108 indicators are partially available and 63 indicators related data are not available at all ${ }^{21}$. 


\section{Date Gap Analysis for SDGs: Bangladesh Perspective}

The govrtnment underlook a comprehensive study of data gap analysis for SDGs monitoring in Bangladesh. The study report titled "Data Gap Analysis for Sustainable Development Goals (SDGs): Bangladesh Perspective", found that Bangladesh was facing a "considerable" data gap for monitoring the SDGs as data of less than one-third of the indicators are readily available while two thirds are either partially available or not available at all. Out of total 241 indicators (for some with repeated use) to monitor against the 169 targets, data of only 70 indicators are readily available while data on 108 indicators are partially available and 63 indicators related data are not available at all ${ }^{20}$.

\section{SDGs Financing Strategy: Bangladesh Perspective}

The General Economics Division (GED), Planning Commission has also conducted an important study on "SDGs Financing Strategy: Bangladesh Perspective" to assess the resources need to implement.

SDGs and map out financial strategy that would require for successful implementation of the SDGs in Bangladesh. The study provides a well-defined framework that outlines the goal and target-wise additional estimated cost at 2015-16 constant price. The 7th FYP extended growth scenario (7 percent plus) projects that the GDP growth rate would be at 9 per cent by FY 2030 .

The report estimates that an additional amount, over the current provision of investment related to SDGs by public sectors and external sources, would be USD 928.48 billion at 2015-16 constant prices. This amount would be required for SDGs implementation over the period of FY 2017-FY 2030, which is 19.75 per cent of the accumulated GDP under 7th FYP extended growth scenario. The annual average cost of SDGs would be USD 66.32 billion (at constant prices) for this period ${ }^{20}$.

\section{National Action Plan to Achieve SDGs in Bangladesh}

The government prepared a "National Action Plan for SDGs Implementation" in accordance with 7th FYP objectives and shared with all relevant ministries for preparation of their respective implementation plan for achieving the SDGs targets ${ }^{20}$.

\section{National Monitoring and Evaluation Framework for SDGs in Bangladesh}

The government has finalized a Monitoring and Evaluation Framework for SDGs implementation. This framework will have a web-based data repository system to facilitate data collection, analysis, progress tracking and reporting ${ }^{20,21}$.

\section{Challenges Ahead}

\section{Resource Mobilization}

Traditional sources of funding are insufficient to implement the SDGs. The government needs to find innovative ways of financing both from the public and the private sectors, development partners and ensure effective and efficient ways for utilization. Moreover, the implementation of the 7th plan requires total investment of 34.4 percent of GDP by 2020 , of which private sector is expected to provide 26.6 percent of GDP. According to Bangladesh Delta Plan, the investment only for climate change, environment and water related projects account for 1.8 percent of GDP by 2020 . The resource gap is yet huge; public spending is only 0.8 percent of GDP on water sector projects, which has been highly inadequate ${ }^{2 l}$.

\section{Population momentum}

Bangladesh population has been growing rapidly, going from just over 108 million in 1990 to 160 million in 2016. Population has been projected to grow to over 200 million by 2050 . A large population together with high population growth require a faster growth of the agricultural production to ensure food and nutritional security. The growth rate of crop sector has been declining. The increase in agricultural production will inevitably put significant pressure on the environment and put pressure on resource availability for human development ${ }^{2 l}$.

\section{Unplanned urbanization}

Bangladesh has been experiencing a rapid increase in the urban population, in 1990, 20 percent of the population lived in urban areas, this has increased to 35 percent in 2016 and it is expected to overtake the share of rural population approximately in 2040. The rapid migration to urban areas and the inadequate infrastructure and accessto open space to meet the growing demand is a serious problem for the country ${ }^{2 l}$.

\section{Natural disasters and climate change}

Bangladesh experiences frequent natural disasters, these can lead to deaths, damage of the infrastructure and economic assets, and have a negative impact on the livelihood of people, particularly ones living in poverty. Bangladesh is considered one of the most climate vulnerable countries, 5th of the most hazard prone countries of the world. Climate change will intensify the natural hazards the country already faces ${ }^{21}$.

\section{Utilization of resources}

Availability of resources does not necessarily guarantee the success in SDGs. Efficient and effective use of resources can be more instrumental than just having adequate resources. In this connection, it is important to assess what resources are needed, how resources are used and for whom the resources should be used ${ }^{2 l}$.

\section{Skill development and quality education}

Around 13 million 15-29 aged young population is not in education, employment and training according to LFS 2015-16, which suggests that a large number of young population remain unutilized. If they can be trained up and provided with education and employment, the scenario will be totally different. This will have a long term consequences in per capita income, growth, poverty and health outcome. Further, improving quality of education in recent times poses a big concern ${ }^{21}$. 


\section{Competitiveness}

Despite, Bangladesh for the first time has been placed in the top 100 (99 out of 137 countries) in 2017 in theWorld Economic Forum's Global Competitiveness Report, yet corruption is still the major obstacle for doing business in Bangladesh. Bangladesh has to keep up the momentum of on-going reforms to make smoother business climate reducing the transaction cost substantially. The realization of One-stop Service Act-2017 will be a landmark step in attracting investment from abroad ${ }^{22}$.

\section{Governance challenges}

There is no alternative to improve governance in order for growth to be more sustainable and pro poor. Yet Bangladesh has made notable progress in governance indicators, there are scope for much improvement. Governance issue is particularly critical in the use of public resources, service delivery of institutions, transports, law enforcement, judiciary, land administration, tax and customs, as they are deemed corrupted service providers in Bangladesh. Digitalization can be an effective tool to address these governance challenges ${ }^{22}$.

\section{Taming inequality and regional disparity}

The declining share of bottom 5 percent income (the share of national income was 0.78 percent in 2010 and 0.23 percent in 2016) and increasing share of top 5 percent income means that unless inequality issues are rightly addressed, the country will have to face the bitter experience of social unrest, marginalization to a greater degree in the forthcoming days. Further poverty is severely intense in some districts and the disparity is widespread. Kurigram has population with 70.8 percent under upper poverty line, followed by Dinajpur with 64.3 percent and Bandarban with 63.2 percent respectively while the incident of poverty in Narayanganj is just 2.6 percent. National average of below poverty is 22.37 percent in 2017 as projected in 7th FYP $22,23,24$.

\section{Blueprint of Bangladesh Implementing of SDG 2030}

\section{Investment in human development}

Bangladesh witnessed that investment in girl's education, immunization, primary education, family planning and basic health services in the 1980s and 1990s yielded positive outcome recognized in MDG era. The government has to continue its effort in human development particularly in basic health services, ensure quality education; training and skill development as the optimal goal of development of creating knowledge based society ${ }^{24}$.

\section{Overcoming infrastructure gap}

Bangladesh has to pay attention in overcoming the infrastructure, transport and communication gap to harness growth and deliver what an upper middle income country look like. Fast track projects are such kind of efforts which deserve to be continued.

\section{Quality education and investment in research}

The next big concern of Bangladesh will be to ensure quality education. LFS 2015-16 suggests unemployment rate is the highest for those with tertiary education, which is staggeringly 9 percent. We have very low budgetary support for research that is well below 1 percent of GDP. In order to be an upper middle income country, the government will have to increase allocation for research, innovation and technology, along with being supportive to private sector $^{24}$.

\section{Adoption of Innovation, digitalization and one stop service}

The world is moving very fast in adopting new technologies in the finest era of human civilization. It is important for Bangladesh to cope with the competitiveness it is likely to face in trade and other sector by adopting of newer technologies that may reduce the global challenges following graduation from LDCs. Introducing one stop service for business investments will be a breakthrough in the area of competitiveness. Our development partners should come forward to help Bangladesh in transfer of technologies in the spirit of Goal 17 of the SDGs ${ }^{24}$.

\section{Building strong institutions and improving governance}

Institutions can play the most vital role in shaping the democratic value, ensuring accountability, justice, and fairness. Weak institutions can be treated nothing more than a burden in any state. The government needs to continue its efforts in building strong institutions manning with highly skilled personalities.

\section{Female labour force participation}

It is undeniable that the country saw a rise in female participation in the labour force over the last decade, yet the participation rate is just 36 percent well below the global average of 49 percent. It is understandable that how female participation even with the global average can be a formidable force of growth, poverty reduction, empowerment and inclusiveness. Female participation will need to be encouraged through incentive policy like maternal leave with payment, compliant workplace, and day care facility. The increasing share of female students in vocational and technical education with stipend should be a priority ${ }^{24}$.

\section{Diversification of export}

The export basket of Bangladesh is concentrated to a number of items, which should draw substantial attention to the policy makers. The diversification issue has been roared long ago but few have come up with solutions. It is also a matter of time on how diversification of and within products evolved over time. The government has been providing incentives to infant industries over a long period. The business community must understand that incentives from the government can not be for good. They also have to look for improving their own competitiveness $^{24}$.

\section{Inequality issues}

Despite progress in reducing poverty head count rates, around 39 million people still live in poverty and approximately 21 million live in extreme poverty (\$1.90 a day). Some of the factors that correlate with poverty are limited access to financial resources, human resources and natural and health shocks. Income Gini Coefficient 
reflecting inequality is considered high (0.48). Inequality has to be brought down to attain SDG-10. That is, average income growth of lower 40 percent of population must be higher than the average income increase of overall population. Further, inequality should not be limited to just income poverty. The time for Bangladesh has come to introduce multidimensional poverty addressing non-monetary aspects of poverty in measuring inequality ${ }^{24}$.

\section{North-South, South-South, triangular cooperation}

There is a growing evidence of partnership that can propel shared prosperity. Apart from benefiting from regional building blocks, the government must continue to seek $\mathrm{G} 2 \mathrm{G}$ initiatives from new destination. The $\mathrm{G} 2 \mathrm{G}$ initiative is likely to gear up establishing targeted economic zones. The Policy for Implementing PPP Projects through Government to Government (G2G) Partnership, 2017 is an on time effort made by the government. The government will need to promote Business to Business initiative in terms of manpower recruits ${ }^{25}$.

\section{Conclusion}

The potential gain from an action plan based on key SDGs policy strategies that built upon the co-creation of new knowledge among countries, Govt. \& Non Govt. institutions \& indeed for most countries achieving the goals may well depend on it.SDGs demand concerted and collective efforts with strong political commitment at all levels. Bangladesh has incorporated priorities of SDGs in all her development policies. The Government has adopted an inclusive approach to development so that the poorest and the most vulnerable section of the country can be integrated into its national development efforts. As the country moves ahead, challenges in several areas, including in resource mobilization and data management, will have to be addressed. Bangladesh is confident to set the example of a leading SDGs achiever.

Conflict of Interests: None.

\section{Acknowledgement}

The authors thanks to Muhammad Alauddin Khan Akash, B.Pharm, M.Pharm who working in International Business Department, Biopharma Ltd, for his assistance in preparing article.

\section{References}

1. Engagement on SDG Implementation in Bangladesh, "Consultation on Stakeholders" Presentation by Dr. Shamsul Alam, Member Planning Commission, 2016 March 30.

2. Perspectives and Recommendations from Bangladesh Civil Society, People's Forum on MDGs, published by CAMPE in 2013 September.

3. Education Budget Trends in Bangladesh. Dhaka: Center for Policy Dialogue and Campaign for Popular Education CPD and CAMPE, 2016.

4. www.undp.org/content/undp/en/home/librarypages/sdgs/transitionaryfrom-the-mggs-to-sdgs.html

5. http//wri.org/blog/2015/09/key-challenges-sdgs

6. Bangladesh Proposal to UN, General Economics Division, Planning Commission, 2013 June.
7. "Transforming Our World: The 2030 Agenda for Sustainable Development." New York: United Nations, 2015.

8.https://www.ti-bangladesh.org/beta3/index.php/en/highlights/5322-sustainable-development-goal-

16-preparedness-progress-and-challenges-of-bangladesh-a-study-of-selected-targets-executive-summary-en glish

9. http://www.safeworld.org.uk

10. http://dhakatribune.com

11. Education 2030 Framework for Action, World Education Forum, Incheon, Korea, UNESCO, 2015 May.

12. Quarterly Labour Force Survey 2015-16, Bangladesh. Dhaka: Bangladesh Bureau of Statistics, 2017.

13. Report on Bangladesh Sample Vital Statistics 2016. Dhaka: Bangladesh Bureau of Statistics (BBS), 2017.

14. Chowdhury, A. M., Bhuiya, A., Chowdhury, M. E., et al. The Bangladesh paradox: exceptional health achievement despite economic poverty. The Lancet. 2013: 1734-1745.

https://doi.org/10.1016/S0140-6736(13)62148-0

15. Dreze, J., Sen, A. An Uncertain Glory: India and its Contradictions. Princeton. NJ. Princeton University Press; 2013.

https://doi.org/10.23943/9781400848775

https://doi.org/10.2307/j.ctt32bcbm

16. Bangladesh Out of the basket, Economist. 2012, November 2 .

17. Delta Vision, Goals and Strategies. General Economics Division, Dhaka, 2015.

18. Data Gap Analysis for Sustainable Development Goals (SDGs) Bangladesh Perspective. Dhaka: General Economics Division (GED), 2017.

19. SDG Need Assessment and Financing Strategy: Bangladesh Perspective. Dhaka: General Economics Division (GED), Planning Commission, 2017.

20. The Bangladesh Demographic and Health Survey 2014. Dhaka: National Institute of Population Research and Training (NIPORT), 2016.

21. The Global Gender Gap Report 2017. Geneva: World Economic Forum (WEF), 2017.

22. www.sdg.gov.bd/uploads/pages/58f8d8e69b131_1

_MDG-Report-Final-Layout.pdf

23. https://thefinancialexpress.com.bd/views/sdgs-challenges-bangladesh-faces-in-achieving-the-goals-151879 1843

24. https://www.thedailystar.net/opinion/economics/can-we-get-there-2030-1447270

25. https://valleyinternational.net/index.php/theijsshi /article/view/1098/1126\#toc 